\title{
Nucleic acid and protein extraction from electropermeabilized E. coli cells on a microfluidic chip
}

Matos, T.; Senkbeil, Silja; Mendonça, A.; Queiroz, J. A.; Kutter, Jörg Peter; Bulow, L.

Published in:

The Analyst

Link to article, DOI:

10.1039/c3an01576a

Publication date:

2013

Document Version

Publisher's PDF, also known as Version of record

Link back to DTU Orbit

Citation $(A P A)$ :

Matos, T., Senkbeil, S., Mendonça, A., Queiroz, J. A., Kutter, J. P., \& Bulow, L. (2013). Nucleic acid and protein extraction from electropermeabilized E. coli cells on a microfluidic chip. The Analyst, 138(24), 7347-7353.

https://doi.org/10.1039/c3an01576a

\section{General rights}

Copyright and moral rights for the publications made accessible in the public portal are retained by the authors and/or other copyright owners and it is a condition of accessing publications that users recognise and abide by the legal requirements associated with these rights.

- Users may download and print one copy of any publication from the public portal for the purpose of private study or research.

- You may not further distribute the material or use it for any profit-making activity or commercial gain

- You may freely distribute the URL identifying the publication in the public portal 


\section{Nucleic acid and protein extraction from electropermeabilized $E$. coli cells on a microfluidic chip}

Received 19th August 2013 Accepted 26th September 2013

DOI: 10.1039/c3an01576a

www.rsc.org/analyst

\author{
T. Matos, ${ }^{\text {ab }}$ S. Senkbeil, ${ }^{c}$ A. Mendonça, ${ }^{\text {b }}$ J. A. Queiroz, ${ }^{\text {b J. P. Kutter }}{ }^{c}$ and L. Bulow ${ }^{\star a}$
}

Due to the extensive use of nucleic acid and protein analysis of bacterial samples, there is a need for simple and rapid extraction protocols for both plasmid DNA and RNA molecules as well as reporter proteins like the green fluorescent protein (GFP). In this report, an electropermeability technique has been developed which is based on exposing $E$. coli cells to low voltages to allow extraction of nucleic acids and proteins. The flow-through electropermeability chip used consists of a microfluidic channel with integrated gold electrodes that promote cell envelope channel formation at low applied voltages. This will allow small biomolecules with diameters less than $30 \mathrm{~A}$ to rapidly diffuse from the permeabilized cells to the surrounding solution. By controlling the applied voltage, partial and transient to complete cell opening can be obtained. By using DC voltages below $0.5 \mathrm{~V}$, cell lysis can be avoided and the transiently formed pores can be closed again and the cells survive. This method has been used to extract RNA and GFP molecules under conditions of electropermeability. Plasmid DNA could be recovered when the applied voltage was increased to $2 \mathrm{~V}$, thus causing complete cell lysis.

\section{Introduction}

The most commonly used bacterial host for recombinant production of nucleic acids and proteins is E. coli..$^{1-3}$ Over the years, several routine procedures have been developed for this bacterium for cell cultivation, harvest, lysis and target biomolecule purification. However, particularly the cell lysis step has often been neglected and the method used for cell opening largely influences the following purification steps to generate a pure end-product., ${ }^{4,5}$ Frequently explored approaches involve externally applied factors based on physical, chemical, mechanical, electrical and/or enzymatic methods. These processes, which often include use of detergents, extreme $\mathrm{pH}$ values or temperature shifts, can be detrimental to the structural maintenance and integrity of sensitive molecules such as plasmid DNA (pDNA), RNA or proteins. The method used for lysis also influences the starting level of contaminating compounds originating from the host cells.

Purified bacterial pDNA has several applications, notably as DNA vaccines, in which the vector expresses a specific structural gene. ${ }^{6}$ This clinically oriented approach requires access to substantial amounts of highly purified pDNA preparations. ${ }^{7}$ Beside DNA, small RNAs have also become important targets for

${ }^{a}$ Pure and Applied Biochemistry, Department of Chemistry, Lund University, PO BOX 124,S-22100 Lund, Sweden. E-mail: Tiago.matos@tbiokem.lth.se; Leif.bulow@ tbiokem.lth.se; Tel: +46462229594

${ }^{b}$ Health Sciences Research Centre, University of Beira Interior, Covilhã, Portugal. E-mail:jqueiroz@ubi.pt; mendonca@ubi.pt

${ }^{c}$ Department of Micro and Nanotechnology, Technical University of Denmark, Kgs. Lyngby, Denmark.E-mail: silja.senkbeil@gmail.com; joerg.kutter@nanotech.dtu.dk scientific investigation particularly due to their regulatory roles in cell development. ${ }^{8}$ Additionally, messenger RNAs are important carriers of genetic information that often need to be isolated for further characterization of cellular expression patterns. ${ }^{9}$ Taken together, the further exploitation of these areas would benefit from the development of a holistic strategy for isolation, extraction, ${ }^{10}$ and chromatographic purification ${ }^{11}$ of nucleic acids. Furthermore, proteins represent an important target group of biomolecules in studies related to research matters within molecular biology and biochemistry. Particularly, some proteins have attracted a more general interest, e.g., green fluorescent proteins (GFPs), which are being extensively used as reporters in characterization of protein complexes, ${ }^{12}$ expression profiles and cell imaging. ${ }^{13}$

Due to the intrinsic characteristics of the bacterial envelope, the modified alkaline procedure has become the most frequently explored method for cell lysis in order to extract pDNA. ${ }^{14}$ This method involves the use of highly alkaline conditions and a detergent to dissolve the lipid cell membranes and release the cellular contents of nucleic acids from the cytoplasm. However, RNA cannot be prepared and isolated by the same method. Extraction of RNA molecules is thus more complex and often includes an acid guanidinium thiocyanatephenol-chloroform step, where the DNA fraction is removed after multiple centrifugations. ${ }^{10}$ In the case of protein extractions, there are several technical hurdles associated with the cell lysis that need to be considered for improving the recovery of the product. Such concerns include for instance methods to refold proteins from inclusion bodies ${ }^{15,16}$ or remove protein aggregates. ${ }^{17}$ These issues must be considered during planning 
of the extraction process. In most instances, additional purification steps, using aqueous two-phase systems or different chromatography based methods are required to obtain acceptable purities of DNA, ${ }^{18-20}$ RNA $^{11,21}$ and GFP. ${ }^{22,23}$

During recent years, the advances in micro- and nano-scale techniques for various analytical and preparative procedures have been remarkably rapid. Different technologies have thus been developed for separation and purification of nucleic acids. ${ }^{24}$ In addition, microfluidic chip electrolysis to achieve cell lysis has been proven to be useful for characterization of $\mathrm{DNA}^{25,26}$ and low molecular weight RNAs. ${ }^{8}$ Such electrolysis is initiated by the destabilization of the lipid bilayer of the bacterial cells, and several studies have been performed to characterize the lipid cell membrane behavior. For instance, Pogodin et al. have examined the permeation of small molecules through lipid bilayers, ${ }^{27}$ where permeability proved to be particularly dependent on the size of the target molecule.

In this study, we have extended the use of microfluidics to control the degree of cell opening to obtain a targeted release of biomolecules from the cells. The approach is based on electroporation, which is a simple and fast procedure well-known since the 1980's. ${ }^{28-31}$ Electroporation has mainly been explored for cell transformation and studies of pore formation, ${ }^{30-32}$ but lately it has been adopted in other fields, notably for tumor ablation. ${ }^{33}$ The occurring membrane destabilization phenomenon can be reversible and transient or irreversible resulting in cell lysis. ${ }^{34}$ This phenomenon has been described as Maxwell deformation, ${ }^{31}$ where the lipid bilayers are reorganized as a response to an applied voltage. A channel is formed due to the presence of water, forcing the lipids to reorganize in order to minimize exposure of the hydrophobic sites. ${ }^{35}$ A transient channel is thereby created allowing migration and diffusion of cytosolic molecules to the surrounding medium. This temporary permeability allows for the migration of molecules such as pDNA, RNA and proteins. In our study, we induced electropermeability on the bacterial envelopes using a simple microfluidic channel with integrated gold electrodes, which promoted destabilization of the membrane bilayers using a very low applied voltage (Fig. 1). Our approach intends to promote a reversible electroporation ${ }^{34}$ in order to avoid complete cell disruption or lysis, even in a nano-scale approach, ${ }^{\mathbf{2 6}}$ and thereby

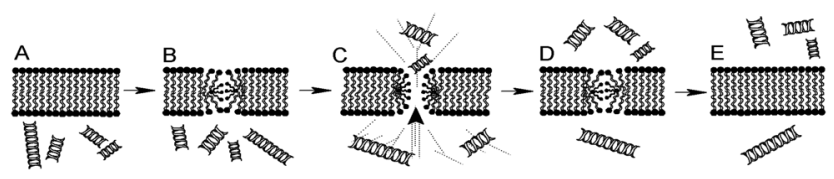

Fig. 1 State transition scheme for the molecular rearrangements of the lipids in the pore edges of the lipid vesicle membrane. (A) The closed bilayer state. The external electric field causes ionic interfacial polarization of the membrane dielectrics, analogous to a parallel plate capacitor. (B) The induced membrane field, leading to water entrance in the membrane to produce pores. In the pore, the lipid molecules are turned to minimize the hydrophobic contact with water. (C) The open pore will allow the transitions of molecules and ions from both sides of the membrane. (D) The membrane stabilizes slowly after moving out from the electrical field. (E) The membrane returns to the initial conformation. minimize the level of contaminants in the starting samples used for characterization of the target molecule. By exploiting different voltage settings, we could thus control the degree of cell opening, which in turn can greatly facilitate subsequent purification steps.

\section{Experimental}

\section{Chip design}

The microfluidic chip consists of a microfluidic channel with four arrays of interdigitated gold electrodes on the top and bottom of the channel. Each array contains a set of ten electrodes with an electrode width of $560 \mu \mathrm{m}$ and a pitch of $1120 \mu \mathrm{m}$. The electrode length is defined by the microfluidic channel width, i.e., $500 \mu \mathrm{m}$. The gold electrodes were fabricated by standard photolithography, e-beam deposition and subsequent lift-off, as described by Illa et al. ${ }^{36}$ Briefly, cyclic olefin copolymer (COC) foil (Topas 5013L, $254 \mu \mathrm{m}$ thick, Topas Advanced Polymers Inc., Florence, KY, USA) was manually cut in 4 inch wafer size, spin-coated (RC 8 spincoater, SÜSS MicroTech AG, Munich, Germany) with a $1.5 \mu \mathrm{m}$ thick AZ5214E image reversal photoresist (MicroChemicals GmbH, Ulm, Germany) and patterned by UV exposure (MA6 mask aligner, SÜSS, MicroTech AG, Munich, Germany). After reversal baking in a convective oven at $120^{\circ} \mathrm{C}$ for $25 \mathrm{~min}$ and $30 \mathrm{~s}$ flood exposure, the developed negative resist pattern was deposited with a $200 \mathrm{~nm}$ gold layer by e-beam deposition (SCM 600, Alcatel, France). The excellent chemical inertness of COC allowed an acetone lift-off, to release the gold electrode structures.

The microfluidic chip was built of three layers, where the top and bottom electrode foil not only provide the electrodes but also seal the microfluidic channel that was cut into the middle layer. A $62 \mathrm{~mm}$ long and $500 \mu \mathrm{m}$ wide channel was cut by micromilling in COC foil; additionally two windows were cut into the foil that allow the electric connection to the electrodes. Holes for microfluidic connection were drilled into the top electrode layer. All three layers were cleaned in a 10 min isopropanol ultrasonic bath, flushed with deionized water and dry blown with nitrogen. Before lamination, the bonding surfaces were exposed to UV light (5000-EC, Dymax Europe GmbH, Wiesbaden, Germany, measured intensity: $40 \mathrm{~mW} \mathrm{~cm}^{-2}$ at $\lambda=$ $365 \mathrm{~nm}$ ) for $30 \mathrm{~s}$ to photolytically degrade the surface and enhance the bonding strength of the mating parts. ${ }^{37,38}$ After surface activation, the three layers were manually aligned, so that the electrodes on the bottom and top layers faced each other and the stack was bonded at $120{ }^{\circ} \mathrm{C}$ with a bonding force of $10 \mathrm{kN}$ for $10 \mathrm{~min}$, using a manual hydraulic laboratory press (P/O Weber, Remshaldern, Germany). ${ }^{39,40}$

The thickness of the channel was defined by the foil thickness. For this series of chips, a $254 \mu \mathrm{m}$ thick foil was used, leading to a channel thickness of $254 \mu \mathrm{m}$ and a channel volume of $7.87 \mathrm{~mm}^{3}(7.87 \mu \mathrm{L})$. The residence time of the cells inside the chip was approximately 2.4 to $4.7 \mathrm{~s}$, depending on the flow rate.

A poly(methyl methacrylate) (PMMA) holder was fabricated in-house by micromilling, as represented in Fig. 2. The PMMA holder seals the microfluidic inlet and outlet with rubber o-rings and connects the chip via teflon tubings to a HPLC 

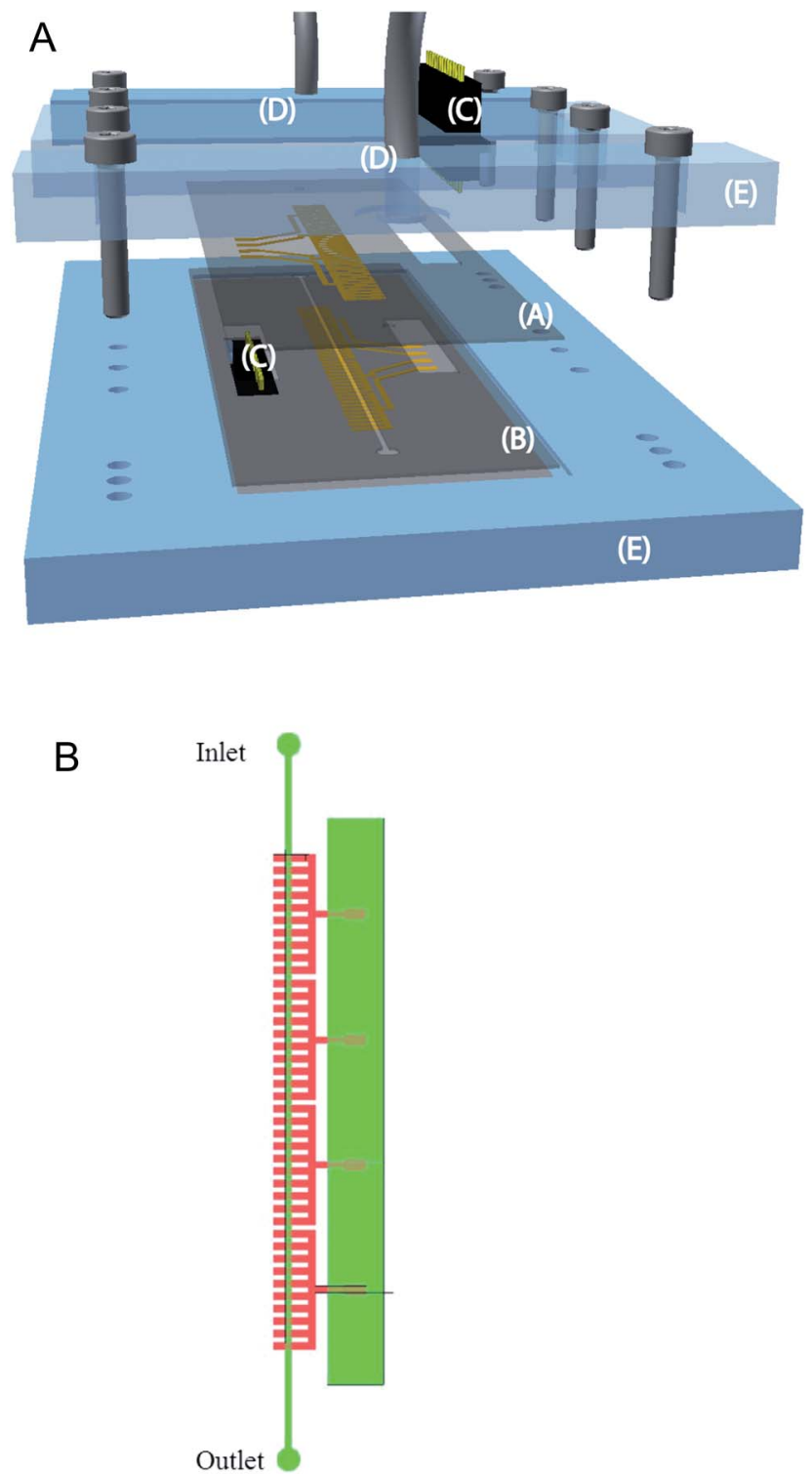

Fig. 2 (A) - Schematic drawing of the electropermeabilization setup. The exploded view shows the top electrode layer $(A)$, and the middle channel with bottom electrode array (B). Spring loaded connectors are pressed against the contact pads of bottom and top electrodes (C). The fluidic connection (D) is sealed via o-rings (not shown). (E) PMMA holder. (B) - Two-dimensional design of the bottom layer of the chip; red represents the electrode array and green the chip structure and channel.

pump (2150, LKB Bromma, Sweden) and collection vessel, respectively. Spring loaded connectors (8PD series, Preci-Dip SA, Delémont, Switzerland) were slightly pressed against the electrode contact pads to ensure a good electrical contact of both, bottom and top electrode arrays. The electrical field between the facing electrodes was applied via a DC power supply (HQ Power PS1502A, Gavere, Belgium) that was connected to the contact pins of the spring-loaded connectors.

\section{E. coli cells examined}

E. coli $\mathrm{DH} 5 \alpha$ harboring the pUC18 (2.686 bp) plasmid was used in the electropermeabilization tests. The cells were grown in a
Terrific Broth (TB) medium (20 $\mathrm{g} \mathrm{L}^{-1}$ tryptone, $24 \mathrm{~g} \mathrm{~L}^{-1}$ yeast extract, $4 \mathrm{~mL} \mathrm{~L}^{-1}$ glycerol, $0.017 \mathrm{M} \mathrm{KH}_{2} \mathrm{PO}_{4}, 0.072 \mathrm{M} \mathrm{K}_{2} \mathrm{HPO}_{4}$ ) supplemented with $100 \mu \mathrm{g} \mathrm{mL} \mathrm{m}^{-1}$ of ampicillin while being cultivated by shaking at $250 \mathrm{rpm}$. The process was terminated at the late exponential phase of bacterial growth. For reference purposes, pure plasmid DNA was also prepared using conventional alkaline lysis with the Qiagen plasmid maxi kit (Hilden, Germany).

E. coli TG1 cells expressing a green fluorescent protein (GFPuv) were also used as a marker protein to examine the degree of cell opening in the microchip electropermeability experiments. The growth was carried out in $1 \mathrm{~L}$ flasks at $250 \mathrm{rpm}$ shaking and $37{ }^{\circ} \mathrm{C}$, using a TB medium supplemented with $100 \mu \mathrm{g} \mathrm{mL}{ }^{-1}$ of ampicillin and induced with isopropyl $\beta$-D-1thiogalactopyranoside (IPTG) at an $\mathrm{OD}_{600} \approx 0.2$ as described by Becker et al. ${ }^{41}$ This strain simultaneously produces two GFPs with different sizes, which allows for monitoring of different protein release levels from the electropermeabilized cells. The cultivation was terminated in the late exponential growth phase. For reference purposes, the GFPuv protein was extracted using cell lysis on a Q Sonica Q500 sonicator (Sonics \& Materials Inc., Newtown, CT, USA) with a microtip 4420 for $10 \mathrm{~min}$ with $3 \mathrm{~s}$ pulses ( $25 \%$ amplitude). ${ }^{37}$

\section{Voltage effects on cell opening}

In order to screen for the sensitivity of the bacterial cells to exposure to increasing voltages, different voltages, up to $2.5 \mathrm{~V}$, were applied perpendicularly over the channel. The bacteria were suspended in a $10 \mathrm{mM}$ citrate buffer $(10 \mathrm{mM} \mathrm{NaCl}, 30 \mathrm{mM}$ glucose, $\mathrm{pH}$ 5.8) and pumped through the chip at a constant flow-rate of $0.2 \mathrm{~mL} \mathrm{~min}^{-1}$. Fractions were collected and cells were recovered by centrifugation. The supernatant was used for further spectrophotometric and electrophoresis analyses. The pellet was collected for cell viability measurements.

The microfluidic channel was rinsed between runs with MilliQ water to remove possible contaminants.

\section{Qualitative analyses of nucleic acids and GFP}

Nucleic acids from permeabilized and lysed E. coli cells were examined using $1 \%$ agarose gels stained with Gel Red $(0.6 \mu \mathrm{g}$ $\mathrm{mL}^{-1}$ ). Electrophoresis was carried out at $100 \mathrm{~V}$ with a TAE buffer (40 mM Tris base, $20 \mathrm{mM}$ acetic acid and $1 \mathrm{mM}$ EDTA, pH 8.0). The gels were observed under UV light and Quantity One software (BioRad, CA, USA) was used to quantify DNA and RNA concentrations. DNA and RNA samples were also quantified by a Nanophotometer Pearl (Implen GmbH, Munich, Germany) at $260 \mathrm{~nm}$. The ratio of absorbance at $260 \mathrm{~nm}$ and $280 \mathrm{~nm}$ was used as a first step to screen sample purity.

The quantification of GFPuv was made by fluorescence measurements using a PTI quantamaster 40 (Photon Technology International, NJ, USA). Excitation and emission wavelengths were $390 \mathrm{~nm}$ and $600 \mathrm{~nm}$, respectively. Additionally, protein purities and expression levels were also monitored by $22 \%$ sodium dodecyl sulphate-polyacrylamide gel electrophoresis (SDS-PAGE) with a Page Ruler Unstained Protein Ladder from 
Thermo Scientific (Rockford, IL, USA) as molecular weight standards.

\section{Cell viability analysis}

To quantify the number of viable cells in the cultures, the cells were diluted and plated on petri dishes after the experiments. The colony numbers were counted after 12 hours and cell concentrations were determined.

\section{Results and discussion}

\section{Electropermeabilization for isolation of nucleic acids}

The degree of cell opening was directly correlated with the applied voltage. When a low voltage was used, i.e., equal to or below $0.5 \mathrm{~V}$, no harmful effects were observed on the cells and the viability was close to $100 \%$ after the cells had passed the channel. However, when the running buffer was analyzed, high levels of nucleic acids could be detected. When investigating the contents of the cell suspension using agarose gel electrophoresis, substantial concentrations of low molecular weight RNA molecules were detected (Fig. 3). Metabolically active E. coli cells thus contain high levels of transfer RNA (tRNA), which constitutes approximately $80 \%$ of the total cellular RNA, ${ }^{\mathbf{4 2}}$ and these molecules could be observed in the supernatant after passage through the channel. Even though a major fraction of total cellular RNA could be extracted from the cells at $0.5 \mathrm{~V}$, the cells remained viable after electropermeabilization (Fig. 4). When the voltage was increased further, substantial lysis occurred, however. The extraction of RNA increased up to an applied voltage of $2 \mathrm{~V}$, but decreased again thereafter. When these higher voltages were applied over the channel, several other detrimental effects were observed in the system, such as attachment of cell debris to the electrodes as well as partial degradation of the electrodes themselves. The maximal applied voltage was therefore generally limited to $2 \mathrm{~V}$ for the remainder

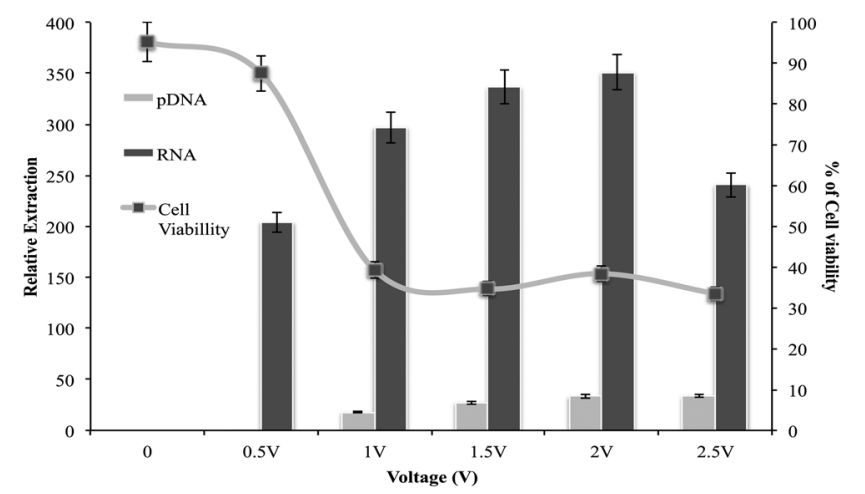

Fig. 3 Extraction of RNA and pDNA after passage of bacteria through the microchannel. Cell viability and nucleic acid extraction, as determined after agarose electrophoresis, were measured in relation to the applied voltage. $10 \mathrm{mM}$ citrate containing $10 \mathrm{mM} \mathrm{NaCl}, 30 \mathrm{mM}$ glucose, $\mathrm{pH}$ 5.8, was used as a carrier buffer. The extraction results are expressed in relative terms and are corrected for the low background levels at $0 \mathrm{~V}$. The error bars indicate standard deviations based on three independent extraction tests and five viability determinations.

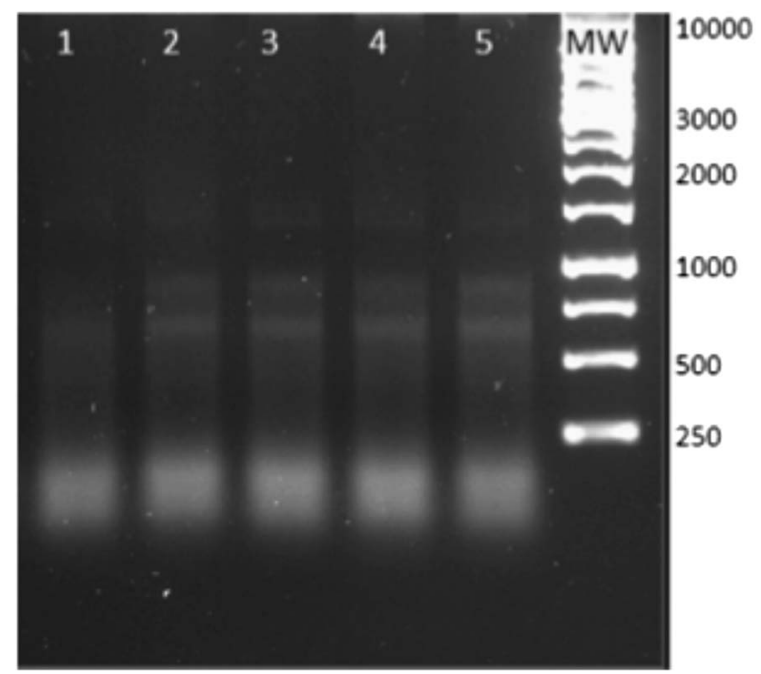

Fig. 4 Agarose gel electrophoretic analysis of nucleic acids extracted at different voltages. $1-0.5 \mathrm{~V} ; 2-1.0 \mathrm{~V} ; 3-1.5 \mathrm{~V} ; 4-2.0 \mathrm{~V}$; and $5-2.5 \mathrm{~V} ; \mathrm{MW}$ - molecular weight marker.

of the experiments. $2 \mathrm{~V}$ corresponds to a field strength of $7.9 \mathrm{mV} \mu \mathrm{m}^{-1}$.

The results clearly indicate that the cells become permeable upon application of low voltages. A temporary rearrangement of the cell lipid bilayers allows the formation of pores, which in turn allows smaller molecules like tRNA to diffuse out from the cytoplasm. The pores will be closed when the applied voltage is removed again, and the cells can recover. This temporary cell opening does not significantly reduce the viability of the cells ${ }^{\mathbf{4 3}}$ and we could generally recover at least $90 \%$ of the original cell numbers after electropermeabilization with an applied voltage of $0.5 \mathrm{~V}$. For complete recovery the cells need to be exposed to a fresh growth medium for about 30 minutes.

Transfer RNA molecules are small with an average diameter of $20 \mathrm{~nm}$. For larger nucleic acids such as plasmid DNA, the formed pores need to be larger and open for extended time periods. However, this became technically impossible to generate without compromising the viability of the cells. Extraction of pDNA was thus only possible at higher applied voltages, i.e. at 1-2 $\mathrm{V}$, where partial to complete cell lysis occurred.

When comparing the quantitative extraction efficiencies in our system with other common techniques such as alkaline lysis, we were able to obtain 10 to $15 \%$ of the total cellular pDNA in a single run through the channel. By running the same sample multiple times through the channel, higher efficiencies could be obtained, but deposition of cellular debris caused clogging of the channel and extensive rinsing with MilliQ water was required. However, when employing the chip in analytical mode based on a single passage of cells, no cleaning or rinsing was required. Our goal was to achieve very rapid extractions minimizing the time needed for analysis. Additionally, another frequently used method is based on extraction with lysozyme, which often includes a heating step. ${ }^{44}$ Such harsh procedures may harm nucleic acid molecule structure, particularly RNA 
molecules, which limit its practical usefulness. The extraction in the chip is very rapid and no heating of the cell solution was registered after passage of the channel.

\section{Electropermeabilization of $\boldsymbol{E}$. coli expressing GFPuv}

The same screening procedure as described above was used for GFPuv extraction from $E$. coli TG1 cells. GFP is a common reporter protein often used to monitor cellular or metabolic activities. It has a very well-defined $\beta$-can structure where the cylinders have a diameter of $30 \AA$ and a length of $40 \AA$. If GFP is released from the cells we can thereby also estimate the minimum size of the pores that were generated after exposure to the electric field. In addition, due to the well-defined fluorescent properties of GFPuv, the fluorescence signal can be used to quantify the total amounts of protein extracted from the cells. When low voltages of up to $0.5 \mathrm{~V}$ were applied between the electrodes, no or very limited cell lysis occurred, in agreement with the results obtained previously for RNA. When the voltage was increased further, cell lysis occurred exactly in the same way as for $E$. coli $\mathrm{DH} 5 \alpha$. Upon permeabilization at $0.5 \mathrm{~V}, 70 \%$ of the amounts of GFP were released to the supernatant as compared with those under lysis conditions at higher voltages (Fig. 5). In order to further delineate the release of proteins from $E$. coli cells upon exposure to voltages over the channel, the supernatant was examined by SDS-PAGE (Fig. 6). In the used expression system, GFP represents approximately $15 \%$ of the total cellular protein. At $1.5 \mathrm{~V}$, the GFP level was $42 \%$ of the total protein extracted, clearly indicating a preference for release of smaller proteins. The extraction thereby allowed for a 2.8 -fold enrichment of GFP simply by passing the cells through the microfluidic channel. In the case of small proteins such as GFPuv (26.9 $\mathrm{kDa})$, the extraction can therefore preferably be done by electropermeabilization, which allows for an initial selection of protein size. In addition, this process is very rapid compared with the more time-consuming size fractionation processes based on, e.g., chromatography. This size exclusion effect can

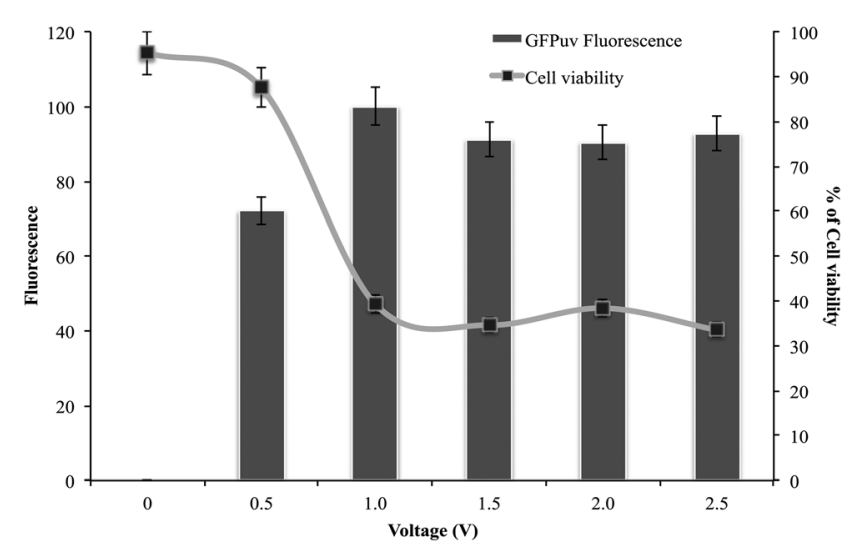

Fig. 5 Voltage effects on the extraction procedure of the reporter protein GFPuv using a $10 \mathrm{mM}$ citrate buffer containing $10 \mathrm{mM} \mathrm{NaCl}, 30 \mathrm{mM}$ glucose, pH 5.8. GFP fluorescence of the supernatants and cell viabilities are presented on the $y$-axis. The error bars indicate standard deviations based on three independent extraction tests and five viability determinations.

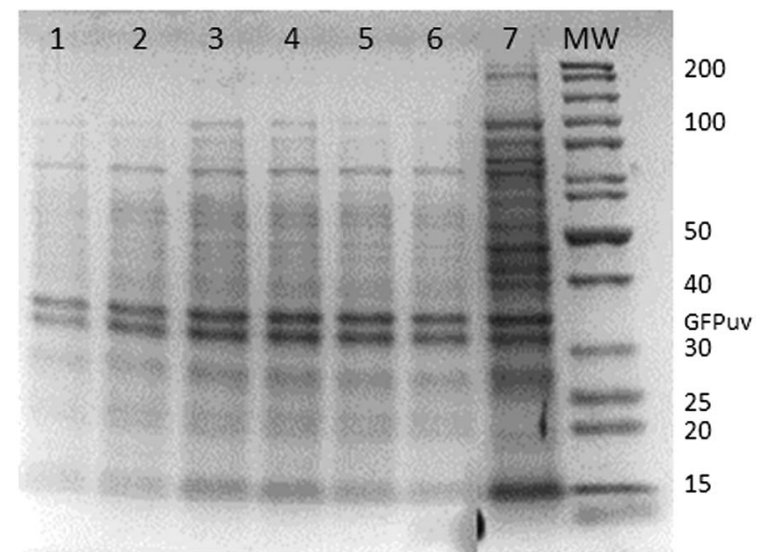

Fig. 6 SDS-PAGE for GFP extraction from E. coli TG1. $1-0.3 \mathrm{~V} ; 2-0.5 \mathrm{~V} ; 3-1.0 \mathrm{~V}$; $4-1.5 \mathrm{~V} ; 5-2.0 \mathrm{~V} ; 6-2.5 \mathrm{~V}$; and 7 - sample control from sonication lysis; MW molecular weight marker.

therefore be utilized as a first elimination step to remove larger host cell proteins or other cellular components.

\section{Other parameters important for cell opening}

Besides voltage effects, there are several other parameters for electropermeabilization of cells and lysis that need to be considered, including cell concentration injected into the channel, buffer composition and flow-rate. When these different conditions were examined, the potential was kept constant at $2 \mathrm{~V}$.

Flow-rate. The size of the channel was chosen to optimize cell permeabilization, but the dimensions and fluidic resistance of the channel limited the useful flow-rate to a maximum value of $0.2 \mathrm{~mL} \mathrm{~min}^{-1}$. When lower flow-rates were examined, the extraction was not improved but the risk of cell debris attachment to the electrodes and subsequent electrode passivation that could perturb the continuous electrical field was increased. The highest extraction values were generally achieved using a flow-rate of $0.2 \mathrm{~mL} \mathrm{~min}^{-1}$, and this value was therefore kept constant throughout the study.

Buffer composition. When using electropermeabilization for isolating intracellular biomolecules, it is important to characterize the behavior of the cellular envelope upon exposure to differences in osmotic pressure. In addition, osmotic stress

$\mathrm{NaCl}$ concentration effect

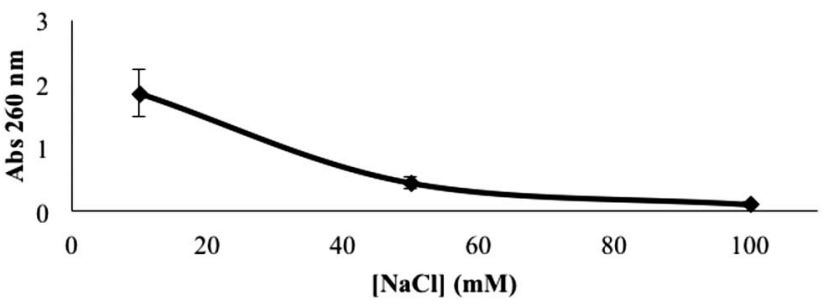

Fig. 7 Nucleic acid extraction as a function of salt concentration in the lysis process. Salt concentrations used were 10,50 and $100 \mathrm{mM} \mathrm{NaCl}$. The process was operated at a constant flow rate of $0.2 \mathrm{~mL} \mathrm{~min}^{-1}$ using an applied voltage of $2 \mathrm{~V}$. The results represent an average of three independent measurements. 


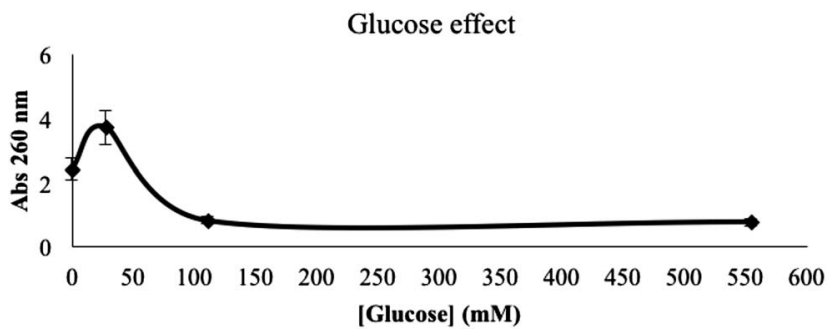

Fig. 8 Effects of glucose concentration on extraction efficiency of nucleic acids The process was operated at a constant flow rate of $0.2 \mathrm{~mL} \mathrm{~min}^{-1}$ using an applied voltage of $2 \mathrm{~V}$. The results represent an average of three independent measurements.

influences the intracellular mobility of particularly larger biomolecules such as GFP and nucleic acids. The internal diffusion coefficient, $D_{\text {median }}$, of proteins like GFP has been estimated to be $3 \mu \mathrm{m}^{2} \mathrm{~s}^{-1}$ under isosmotic conditions. ${ }^{38}$ The translational diffusion of proteins in the cytoplasm of $E$. coli is thus still high in relation to residence time of the cells in the channel. However, different buffer compositions need to be examined focusing on ionic strength and possible osmotic protection by particularly carbohydrates. The influence of salt $(\mathrm{NaCl})$ concentrations between 10 and $100 \mathrm{mM}$ was determined. The optimal $\mathrm{NaCl}$ concentration in relation to yields of nucleic acids in the tested range, $10-100 \mathrm{mM}$, was identified to be $10 \mathrm{mM}$ (Fig. 7). High salt concentrations appeared to shield the cells and protect the lipid bilayers against lysis. Similarly, the effects of glucose addition to the media were examined and addition of $30 \mathrm{mM}$ glucose improved extraction (Fig. 8). Glucose additions will stabilize the cells and indirectly influence the pore size and pore stability upon exposure to an electric field. If the glucose concentration used is optimized, it is easier to control the entire permeabilization. Such a control also leads to a faster and homogeneous cell recovery.

Cell concentration. The concentration of bacteria in solution is a critical factor that needs to be optimized. At higher cell concentrations, cell suspensions will be highly viscous generating higher back pressures in the system, which in turn may lead to partial cell lysis due to mechanical shearing. In addition, a higher concentration of cells could promote a shielding effect

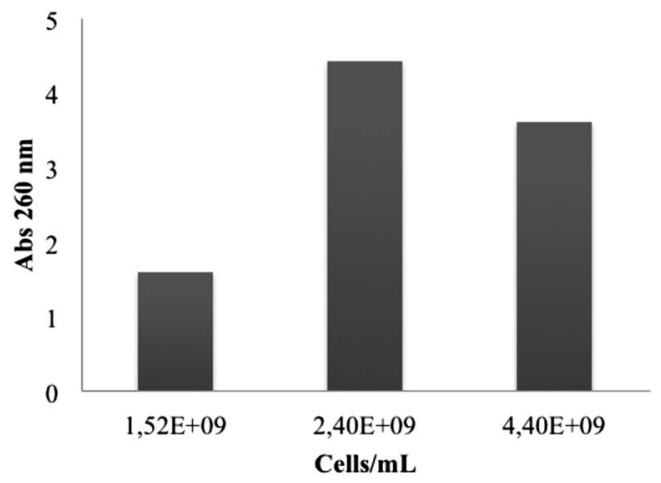

Fig. 9 Influence of cell concentration on the extraction of nucleic acid as determined by measurements of absorbance at $260 \mathrm{~nm}$. of adjacent cells during the passage through the channel, also leading to lower extraction rates. This has often been described as a neighboring effect. On the other hand, lower cell concentrations may be favorable for the system in terms of shielding and viscosity, but the absolute yields of obtained nucleic acids will then be limited. Different cell concentrations were therefore examined and under the conditions examined we observed that $2.40 \times 10^{9}$ cells per $\mathrm{mL}$ gave the highest yields of nucleic acids as determined by absorbance measurements at $260 \mathrm{~nm}$ (Fig. 9).

\section{Conclusions}

We here report a simple protocol for the extraction of nucleic acids and proteins by electropermeabilizing $E$. coli cells in a microfluidic chip with integrated gold electrode arrays. By controlling the applied voltage across the microchannel, the degree of cell opening for two commonly utilized $E$. coli host cell strains, TG1 and DH5 $\alpha$, could be controlled. Both strains behaved identically in terms of permeability and lysis. The represented system has a number of key advantages compared to the available technologies, which are either commercially available or described in the scientific literature. The presented approach is extremely fast for nucleic acid and protein extractions, especially compared to the traditional lysis methods for such molecules. Since no total cell disruption occurs, the method described represents a cleaner extraction way, leading to a simple final sample to be purified using chromatography or any other purification methods available. In addition, the process is less aggressive for extracting DNA, RNA and proteins, since the procedure uses no detergents, $\mathrm{pH}$ variations or high temperatures.

\section{Acknowledgements}

Tiago Matos acknowledges a fellowship (SFRH/BD/47934/2008) from FCT, Portuguese Foundation for Science and Technology. Silja Senkbeil gratefully acknowledges funding through Copenhagen Graduate School for Nanoscience and Nanotechnology (C:O:N:T) and the National Food Institute at the Technical University of Denmark. Authors would like to thank Dr Per-Olof Larsson and Dr Cedric Dicko, for valuable comments.

\section{References}

1 K. Listner, L. Bentley, J. Okonkowski, C. Kistler, R. Wnek, A. Caparoni, B. Junker, D. Robinson, P. Salmon and M. Chartrain, Biotechnol. Prog., 2006, 22, 1335-1345.

2 F. Silva, L. Passarinha, F. Sousa, J. A. Queiroz and F. C. Domingues, J. Microbiol. Biotechnol., 2009, 19, 14081414.

3 A. M. Lopes, P. O. Magalhães, P. G. Mazzola, C. O. RangelYagui, J. C. M. de Carvalho, T. C. V. Penna and A. Pessoa, Sep. Purif. Technol., 2011, 81, 339-346.

4 F. J. Meacle, R. Lander, P. Ayazi Shamlou and N. J. TitchenerHooker, Biotechnol. Bioeng., 2004, 87, 293-302. 
5 O. Salazar and J. A. Asenjo, Biotechnol. Lett., 2007, 29, 985994.

6 D. M. Prazeres, G. N. Ferreira, G. A. Monteiro, C. L. Cooney and J. M. Cabral, Trends Biotechnol., 1999, 17, 169-174.

7 D. Fioretti, S. Iurescia, V. M. Fazio and M. Rinaldi, J. Biomed. Biotechnol., 2010, 2010, 1-16.

8 P. Vulto, G. Dame, U. Maier, S. Makohliso, S. Podszun, P. Zahn and G. A. Urban, Lab Chip, 2010, 10, 610-616.

9 K. M. Wassarman, A. Zhang and G. Storz, Trends Microbiol., 1999, 7, 37-45.

10 P. Chomczynski and N. Sacchi, Nat. Protoc., 2006, 1, 581-585.

11 R. Martins, C. J. Maia, J. A. Queiroz and F. Sousa, J. Sep. Sci., 2012, 35, 1-10.

12 S. Zhang, C. Ma and M. Chalfie, Cell, 2004, 119, 137-144.

13 A. A. Pakhomov and V. I. Martynov, Chem. Biol., 2008, 15, 755-764.

14 D. E. Taylor and E. C. Brose, Nucleic Acids Res., 1988, 16, 9056.

15 K. Tsumoto, D. Ejima, I. Kumagai and T. Arakawa, Protein Expression Purif., 2003, 28, 1-8.

16 L. Strandberg and S. O. Enfors, Appl. Environ. Microbiol., 1991, 57, 1669-1674.

17 S. E. Bondos and A. Bicknell, Anal. Biochem., 2003, 316, 223231.

18 P. Guerrero-German, R. M. Montesinos-Cisneros, D. M. Prazeres and A. Tejeda-Mansir, Biotechnol. Appl. Biochem., 2011, 58, 68-74.

19 F. Sousa, D. M. Prazeres and J. A. Queiroz, Trends Biotechnol., 2008, 26, 518-525.

20 M. J. Shin, L. Tan, M. H. Jeong, J.-H. Kim and W.-S. Choe, J. Chromatogr., A, 2011, 1218, 5273-5278.

21 R. Martins, J. A. Queiroz and F. Sousa, J. Mol. Recognit., 2010, 23, 519-524.

22 K. Becker, E. Hallgren, E. Carredano, R. Palmgren and L. Bülow, J. Mol. Recognit., 2008, 22, 104-109.

23 S. Fexby, H. Ihre, L. Bulow and J. M. Van Alstine, J. Chromatogr., A, 2007, 1161, 234-241.

24 G. Garcia-Schwarz, A. Rogacs, S. S. Bahga and J. G. Santiago, J. Visualized Exp., 2012, e3890.

25 H. J. Lee, J.-H. Kim, H. K. Lim, E. C. Cho, N. Huh, C. Ko, J. C. Park, J.-W. Choi and S. S. Lee, Lab Chip, 2010, 10, 626-633.
26 T. Geng, N. Bao, N. Sriranganathanw, L. Li and C. Lu, Anal. Chem., 2012, 84, 9632-9639.

27 S. Pogodin, M. Werner, J.-U. Sommer and V. A. Baulin, ACS Nano, 2012, 6, 10555-10561.

$28 \mathrm{~J}$. C. Weaver and Y. A. Chizmadzhev, Bioelectrochem. Bioenerg., 1996, 41, 135-160.

29 E. Neumann and S. Kakorin, Biophys. Chem., 2000, 85, 249-271.

30 S. Kakorin, T. Liese and E. Neumann, J. Phys. Chem. B, 2003, 107, 10243-10251.

31 E. Neumann, S. Kakorin and K. Toensing, Methods Mol. Med., 2000, 37, 1-35.

32 K. C. Melikov, V. A. Frolov, A. Shcherbakov, A. V. Samsonov, Y. A. Chizmadzhev and L. V. Chernomordik, Biophys. J., 2001, 80, 1829-1836.

33 B. Al-Sakere, F. André, C. Bernat, E. Connault, P. Opolon, R. V. Davalos, B. Rubinsky and L. M. Mir, PloS One, 2007, 2, e1135.

34 T. Geng and C. Lu, Lab Chip, 2013, 13, 3803-3821.

35 R. W. Glaser, S. L. Leikin, L. V. Chernomordik, V. F. Pastushenko and A. I. Sokirko, Biochim. Biophys. Acta, 1988, 940, 275-287.

36 X. Illa, O. Ordeig, D. Snakenborg, A. Romano-Rodríguez, R. G. Compton and J. P. Kutter, Lab Chip, 2010, 10, 12541261.

37 A. Bhattacharyya and C. M. Klapperich, Lab Chip, 2007, 7, 876-882.

38 C. W. Tsao, L. Hromada, J. Liu, P. Kumar and D. L. DeVoe, Lab Chip, 2007, 7, 499-505.

39 J. Kameoka, H. G. Craighead, H. Zhang and J. Henion, Anal. Chem., 2001, 73, 1935-1941.

40 B.-Y. Pemg, C.-W. Wu, Y.-K. Shen and Y. Lin, Polym. Adv. Technol., 2010, 21, 457-466.

41 K. Becker, J. Van Alstine and L. Bulow, J. Chromatogr., A, 2008, 1202, 40-46.

42 M. Nilsson, P. T. Kallio, J. E. Bailey, L. Bulow and K. G. Wahlund, Biotechnol. Progr., 1999, 22, 158-163.

43 R. W. Glaser, S. L. Leikin, L. V. Chernomordik, V. F. Pastushenko and A. I. Sokirko, Biochem. Biophys. Acta, 1988, 940, 275-287.

44 K. Zhu, H. Jin, Z. He, Q. Zhu and B. Wang, Nat. Protoc., 2006, 1, 3088-3093. 